Gut, 1960, 1, 36.

\title{
THE EFFECTS OF CORTICOTROPHIN AND CORTICOIDS ON SECRETION FROM DENERVATED GASTRIC POUCHES IN DOGS*
}

\author{
BY \\ S. D. CLARKE, D. W. NEILL, and R. B. WELBOURN \\ From the Department of Surgery, the Queen's University, and the Royal Victoria Hospital, \\ Belfast, Northern Ireland
}

The effects of corticotrophin and of cortisone, methyl prednisolone, and of aldosterone on the gastric secretion of dogs have been investigated. Juice was collected from dogs with denervated pouches under basal conditions and when stimulated with meat extract and with histamine. For each secretion the volume, viscosity, and $\mathrm{pH}$ were measured, and the concentrations of hydrochloric acid, pepsin, sodium, potassium, and chloride estimated.

In the pharmacological doses used all the substances produced similar effects. Volume and acidity of the secretion were increased and there was a decrease in the viscosity of the basal secretion. The concentration of pepsin and of sodium and potassium were decreased while the chloride concentration was unaffected. Cortisone (the only steroid tested in this respect) increased the maximal secretory response to histamine. Three to five days elapsed before any change took place in the secretion.

The effects observed were independent of the glucocorticoid or mineralocorticoid activity of the particular hormone used and were probably due in some measure to a $50 \%$ increase in parietal cell population, associated with a $36 \%$ decrease in peptic cell population, which was demonstrated histologically.

The relationship between the hormones of the adrenal cortex and the secretion of gastric juice is of interest for several reasons. It throws light on the pathogenesis of steroid-induced ulcers, it may be concerned in the development of simple peptic ulceration, and it is certainly of physiological importance. The nature of the relationship has been approached in various ways and those who have studied it have reported conflicting results.

Thus the effects of the administration of corticoids and of adrenalectomy, with and without replacement therapy, have been reported by several workers, while others have studied the structure and function of the adrenal cortices in patients with gastric disorders. We are mainly concerned here with the effects of the administration of corticoids, in pharmacological doses, on gastric secretion in all its aspects.

\section{SECretion OF ACID}

The effects of corticotrophin, cortisone, and other steroids on the stomach in man are uncertain. Some (Hirschowitz, Streeten, Pollard, and Boldt, 1955; Carbone and Liebowitz, 1958) have found that

* Paper presented at the annual meeting of the British Society of Gastroenterology at Belfast on November 6, 1959. they stimulate acid secretion, while others (Winkelstein; 1957; Dreiling, Janowitz and Rolbin, 1958) have found that they do not. These discrepancies may be the result of differences in the doses which were used and in the length of time during which the substances were administered. The concentration of acid in gastric juice is increased in Cuishing's syndrome and restored to normal by adrenatectomy (Kyle, Logan, Neill, and Welbourn, 1956). Corticotrophin and cortisone increase the secretion of acid in the monkey (French, Longmire, Porter, and Movius, 1953), but neither they nor deoxycortone have any stimulatory effect in the rat (Kyle and Welbourn, 1956).

The results of experiments carried out in the dog are no less conflicting. Some (Zubiran, Kark, and Dragstedt, 1952a; Zubiran, Kark, Montalbetti, Morel, and Dragstedt, 1952b) have found that a sustained increase in acid secretion from innervated and denervated pouches is produced by corticotrophin in a dose of $75 \mathrm{mg}$, per day for 10 days and by cortisone in a dose of $100 \mathrm{mg}$. per day for 30 days. Others (Wiederanders, Classen, and Gobbel, 1959) did not find any increase when they gave $300 \mathrm{mg}$. of cortisone daily for $\mathbf{1 0}$ days. Prednisolone is reported to stimulate acid production and to increase the 
volume of both basal and histamine-stimulated secretion from denervated pouches. The effects of corticotrophin and of corticoids given for short periods are also uncertain. Some (Ragins, Dragstedt, Landor, Lyon, and Dragstedt, 1956) did not observe any effects when massive doses of corticotrophin, cortisone, and hydrocortisone were given to dogs with denervated pouches. Others (Plainos and Phillippu, 1958; Villareal, Ganong, and Gray, 1955) found that corticotrophin increased the secretion by the intact stomach, and that the effect persisted after vagotomy. There is uncertainty also about the relationship of the gastric antrum to the hypersecretion produced by corticoids. Some (McGee, Blackburn, Lance, and Scott, 1959) have found that excision of the antrum abolishes the secretory response to cortisone. Others (Zubiran et al., 1952a) report that antrectomy has no effect. Similarly antrectomy has no effect on the secretion induced by corticotrophin (Villareal et al., 1955). Cortisone, instilled locally into denervated pouches, has no effect on secretion (McGee et al., 1959).

\section{Secretion of Pepsin}

There is no general agreement on the effects of adrenal steroids on the secretion of pepsin. Some workers have reported a rise in gastric pepsin and in uropepsin during the administration of corticotrophin (Gray, Benson, Reifenstein, and Spiro, 1951a; Gray, Benson, Spiro, and Reifenstein, 1951b; Hirschowitz et al., 1955) and of prednisolone (Carbone and Liebowitz, 1958) in man and in the dog. Others have found no increase in gastric pepsin or in the pepsinogen of plasma or urine in human subjects when adrenal steroids are infused for short periods (Hirschowitz, London, and Pollard, 1957; Dreiling et al., 1958). It may be, however, that the dosage and duration of administration determine the effect. Hydrocortisone, in doses of $\mathbf{4 0} \mathrm{mg}$. and $\mathbf{1 0} \mathrm{mg}$. per day respectively, have no effect, while the same steroids, given in doses twice this size, cause a definite increase in the excretion of uropepsin (Oka and Aho, 1957). It should be noted that the concentrations of pepsinogen in the plasma and in the urine may not reflect accurately the secretion of pepsin by the stomach. It has, for instance, been found that adrenal steroids increase the clearance of pepsinogen by the kidneys (Hirschowitz et al., 1957).

\section{SeCretion of Mucus}

The effect of corticoids on the secretion of mucus does not appear to have been studied in detail. However, the visible mucus content and the viscosity of the gastric juice (which is related to the concentration of dissolved mucus) are reduced by corticotrophin and corticosterone but not by hydrocortisone (Hirschowitz et al., 1955).

\section{SeCretion of Electrolytes}

Little work has been published on the effects of corticoids on the concentrations of sodium, potassium, and chloride ions in the gastric juice. In one study in the dog the chloride content was found to rise and the sodium and potassium concentrations to fall appreciably after a single injection of corticotrophin (Villareal et al., 1955).

\section{EFFECTS OF AdRENAL INSUFFICIENCY}

Addison's disease in man is often associated with achlorhydria (Rowntree and Snell, 1931). In the rat (Welbourn and Code, 1953; Kyle and Welbourn, 1956) adrenalectomy reduces the volume and the acidity of gastric juice and cortisone subsequently not only restores the secretion but increases it to a supranormal level. Deoxycortone restores the volume, but not the acidity, of the juice after adrenalectomy.

In the dog adrenalectomy abolishes the gastric secretory response to corticotrophin.

The relationship between histamine-induced and corticoid-induced secretion has been studied after adrenalectomy. In a patient with Addison's disease (Stempien and Dagradi, 1954) very little gastric response to histamine was obtained. When cortisone, deoxycortone, and salt were given the response was greatly increased. In the rat (Kyle and Welbourn, 1956) histamine restores the volume and the acidity of gastric juice after adrenalectomy, but does not cause hypersecretion as it does in animals with intact adrenal glands. The restoration of secretion is brought about by a dose of histamine which is much smaller than that required to stimulate secretion in the normal animal. In the dog (Sigel, Bassett, and Cooper, 1957) the response of the stomach to histamine after adrenalectomy varies directly (within limits) with the dose of cortisone administered. A little secretion, however, is still obtained when cortisone is withdrawn. We may conclude that the gastric mucosa is capable of responding to histamine in the absence of endogenous or exogenous corticoids, but that corticoids are necessary for an optimal response.

Destruction of the pituitary in man (Escamilla and Lisser, 1942; Kyle, 1955) and in the rat (Kyle and Welbourn, 1956) reduces gastric secretion even more than does destruction of the adrenals.

\section{Possible Modes of Action}

If, as seems probable from the weight of evidence, corticoids increase the secretion of acid by the stomach, we must ask how they do so. There are several possibilities:

(1) Corticoids sensitize the parietal cells to normal stimuli. 
(2) They cause the liberation of histamine in the vicinity of the parietal cells. The level of histamine in the blood is reduced and the excretion of histamine in the urine is increased by the administration of cortisone (Code and Mitchell, 1953; Mitchell and Code, 1954; Kelemen and Bikich, 1956).

(3) They affect the exchange of electrolytes across the gastric mucosa in the same way as they do across the cells of the sweat glands and the renal tubules. If sodium ions were retained, there might be a compensatory increase in the excretion of hydrogen ions.

(4) They increase the number of parietal cells in the stomach.

\section{Present Investigation}

This investigation, which was done in dogs with denervated gastric pouches, was undertaken with the following objects:

(1) To discover the effects of corticotrophin and of corticoids on the various components of gastric juice.

(2) To discover whether the maximal secretory response to histamine could be enhanced by cortisone.

(3) To elucidate the relationship between the secretion of hydrogen ions and that of other electrolyte ions. For this reason the effects of methyl prednisolone, a relatively pure glucocorticoid, and of aldosterone, a very strong mineralocorticoid, were compared with those of corticotrophin and cortisone. Cortisone itself has both glucorticoid and mineralocorticoid activity.

(4) To find the effect of corticoids on the cellular structure of the gastric mucosa.

\section{MATERIALS AND METHODS}

Eight smooth-haired mongrel bitches weighing 7-14 kg. were used in the "secretion" experiments (1-3 above). Denervated (Heidenhain) pouches were prepared and fitted with "duralumin" cannulae. The animals were not tested for at least five weeks after the operations. They were fasted for 18 hours before all tests. During the experiments control tests were made frequently.

Throughout the experiments (except when they were being fasted before a test) all the dogs were fed on a standard diet consisting of - meal offal and pig starter meal in equal parts. Each dog was fed once daily with a measured quantity sufficient to provide approximately 70 Calories per kilogram per day.

Gastric juice was collected in graduated tubes, and the following estimations were made: (a) volume; $(b) p \mathrm{H}$ by a direct-reading $p \mathrm{H}$ meter; (c) free and total acid by titration against $\mathrm{N} / 20 \mathrm{NaOH}$ with Töpfer's reagent as indicator; $(d)$ pepsin by the modified Mett method (Hawk, Oser and Summerson, 1952); (e) sodium and potassium by flame photometry; $(f)$ chloride by the method of Schales and Schales $(1941) ;(g)$ viscosity by measuring the time taken to fall a measured distance in capillary tubing of standard bore.
In some large specimens the protein content was estimated. The juice was dialysed and dried in a vacuum at $-20^{\circ} \mathrm{C}$. The solid residue was then weighed.

Collections of gastric juice were taken under three sets of conditions:

(1) Basal Secretion.-In these tests the gastric juice was collected for four hours from the unstimulated pouch.

(2) Antral Stimulation.- The gastric antrum was stimulated by the injection of meat extract $(35 \mathrm{ml}$. of a $20 \%$ solution of "bovril" at $p \mathrm{H} \mathrm{5.4)}$ into the stomach through a polythene tube. A standard meat meal had been tried previously but was abandoned because many of the dogs refused to eat it when they were receiving corticoids. Collections were taken for half an hour after the injection.

(3) Histamine Stimulation.-Collections were made after $(a)$ standard tests and $(b)$ after injections to obtain the maximal secretory response.

(a) Standard Tests.-Histamine acid phosphate (B.P.) was injected subcutaneously in a dose of $1 \mathrm{mg}$. of histamine base per $10 \mathrm{~kg}$. body weight. Half an hour before the administration of histamine $5 \mathrm{mg}$. of chlorpheniramine maleate (an antihistaminic drug) was given subcutaneously. Collections were taken for half an hour after the injection of histamine.

(b) Maximal Secretory Response.-The technique was similar to that described by Code (Code, Blackburn, Livermore, and Ratke, 1949). The antihistamine (5 mg.) was injected half an hour before the start of the test and again two and a half hours later. Gastric juice was collected for half an hour from the time of the first injection to ensure that the pouch was secreting at a basal rate. Histamine was then injected every 15 minutes through a polythene tube, which was left lying in the subcutaneous tissues. Each injection contained $0 \cdot 17 \mathrm{mg}$. of histamine base initially and the dose was doubled every hour. The collecting tube was changed every 15 minutes and the test was stopped when an increase in the dose of histamine failed to cause an increase in the volume of gastric juice secreted. This period varied from four and a half to five hours.

Collections were made from the pouches under control conditions and when the animals were receiving corticotrophin or corticoids. Four dogs were tested on each drug. The drugs, doses, and methods of administration were as follows:

(1) Corticotrophin Gel.-Twenty-five clinical units were injected intramuscularly once daily. It was anticipated that this would cause an endogenous secretion of cortisol equivalent to $100 \mathrm{mg}$. of cortisone.

(2) CoRtisone ACETATE (B.P.).-Fifty milligrams were injected intramuscularly twice daily (100 mg. per day). Previous reports had suggested that this dose would stimulate secretion of gastric acid. In some experiments, as noted later, smaller doses were used.

(3) Methyl Prednisolone (6-Methyl-Delta-1-HydroCORTISONE).-Four milligrams were given by mouth at 9.0 a.m. and $8 \mathrm{mg}$. at 5.0 p.m. (12 mg. per day). No parenteral preparation was available. This dose has 
a glucocorticoid effect comparable with that of $100 \mathrm{mg}$. of cortisone.

(4) Aldosterone.-dl - Aldosterone monoacetate, $0.2 \mathrm{mg}$., was injected intramuscularly once daily. This dose has a mineralocorticoid effect comparable with that of $100 \mathrm{mg}$. of cortisone.

All these substances were given for seven to 12 days. Longer periods of administration caused serious complications. An interval of at least three weeks was allowed to elapse between the stopping of one hormone and the starting of another, and collections were taken during this time to ensure that normal secretion had been reestablished.

An estimate of the effect of corticoids on the cellular structure of the gastric mucosa was made as follows. Five control dogs were killed and their stomachs were removed immediately. From each stomach a strip of the gastric wall was taken at a point on the greater curvature 3 in. from the pylorus. This was fixed in $10 \%$ formol saline, embedded in wax, sectioned, and stained with haematoxylin and eosin. Six test dogs were given corticoids for 10 days and then killed and treated similarly. Three of

TABLE I

EFFECT OF CORTICOTROPHIN AND CORTICOIDS ON VOLUME OF GASTRIC JUICE

\begin{tabular}{|c|c|c|c|}
\hline & \multicolumn{3}{|c|}{ Mean Volume of Gastric Juice (ml./ $\frac{1}{2}$ Hour) } \\
\hline & \multirow[b]{2}{*}{ Unstimulated } & \multicolumn{2}{|c|}{ Stimulated } \\
\hline & & Histamine & Meat Extract \\
\hline Control & 0.5 & $7 \cdot 9$ & $3 \cdot 3$ \\
\hline $\begin{array}{l}\text { Corticotrophin } \\
\text { Mean difference* } \\
\text { S.E. of difference } \\
\text { t(D. of } F \text {.) } \\
\text { P }\end{array}$ & $\begin{array}{c}+0.5 \\
0.05 \\
18.3(3) \\
P<0.001\end{array}$ & $\begin{array}{c}+3.9 \\
1.5 \\
3.2(3) \\
0.05>\mathrm{P}>0.02 \\
\end{array}$ & $\begin{array}{c}+3.3 \\
0.5 \\
\begin{array}{c}7.4(2) \\
0.02\end{array} \mathbf{P}^{>}>0.01 \\
\end{array}$ \\
\hline $\begin{array}{l}\text { Cortisone } \\
\text { Mean difference* } \\
\text { S.E. of difference } \\
\text { t(D. of F.) } \\
\text { P }\end{array}$ & $\begin{array}{c}-0.2 \\
0.9 \\
0.03(3) \\
0.8>P>0.7\end{array}$ & $\begin{array}{c}+3.2 \\
0.7 \\
4.5(3) \\
0.05>\mathrm{P}>0.02\end{array}$ & $\begin{array}{c}+4.9 \\
1.4 \\
3.5(1) \\
0.2>P>^{>} 0.1 \\
\end{array}$ \\
\hline $\begin{array}{l}\text { Methyl prednisolone } \\
\text { Mean difference* } \\
\text { S.E. of difference } \\
t \text { (D. of F.) } \\
\text { P }\end{array}$ & $\begin{array}{c}+0.6 \\
0.5 \\
0.2 \quad 2.33(3) \\
0.2>0.1\end{array}$ & $\begin{array}{c}+1.9 \\
1.4 \\
1.4(3) \\
0.3>P P>0.2\end{array}$ & $\begin{array}{c}+4.2 \\
1.3 \\
3.1(3) \\
0.1 \quad>P>0.05 \\
\end{array}$ \\
\hline $\begin{array}{l}\text { Aldosterone } \\
\text { Mean difference* } \\
\text { S.E. of difference } \\
t \text { (D. of } F \text {.) } \\
\mathbf{P}\end{array}$ & $\begin{array}{c}+0.5 \\
0.2 \\
5.13(3) \\
0.02>\mathrm{P}>0.01\end{array}$ & $\begin{array}{c}+2.9 \\
0.9 \\
3.2(3) \\
0.05>P>0.02\end{array}$ & $\begin{array}{c}+3.7 \\
0.4 \\
8.1(2) \\
0.02>P>0.01\end{array}$ \\
\hline
\end{tabular}

The $t$ test for paired data has been used for the statistical analysis in Tables I to VIII.

*Test values minus control values.

TABLE II

EFFECT OF CORTICOTROPHIN AND CORTICOIDS ON THE FREE HCI AND $p H$ OF GASTRIC JUICE

\begin{tabular}{|c|c|c|c|c|c|c|}
\hline & \multicolumn{3}{|c|}{ Mean Free $\mathrm{HCl}$ (mEq./1.) } & \multicolumn{3}{|c|}{ Mean $p H$} \\
\hline & Unstimulated & Histamine & Meat Extract & Unstimulated & Histamine & Meat Extract \\
\hline Control & 0 & 98 & 69 & 5.8 & 1.4 & 1.7 \\
\hline $\begin{array}{l}\text { Corticotrophin } \\
\text { Mean difference* } \\
\text { S.E. of difference } \\
t \text { (D. of F.) } \\
\text { P }\end{array}$ & $\begin{array}{c}+24 \\
1.7 \\
14.5(3) \\
0.01>P>0.001 \\
\end{array}$ & $\begin{array}{c}+39 \\
11.4 \\
3.6(3) \\
0.05>\mathrm{P}>0.02 \\
\end{array}$ & $\begin{array}{c}+58 \\
21 \cdot 3 \\
2 \cdot 7(2) \\
0.2>P>0.1 \\
\end{array}$ & $\begin{array}{c}-2.6 \\
0.4 \\
6.5(3) \\
0.01>P>0.001 \\
\end{array}$ & $\begin{aligned}-0.3 \\
0.001 \\
3.4(3) \\
0.05>\mathrm{P}>0.02 \\
\end{aligned}$ & $\begin{array}{c}-0.6 \\
0.01 \\
69 \\
P<0.001\end{array}$ \\
\hline $\begin{array}{l}\text { Cortisone } \\
\text { Mean difference* } \\
\text { S.E. of difference } \\
\text { t(D. of F.) } \\
\text { P }\end{array}$ & $\begin{array}{c}+16 \\
5.6 \\
2.9(3) \\
0 \cdot 1>P>0.05 \\
\end{array}$ & $\begin{array}{c}+37 \\
9.5 \\
3.9(3) \\
0.05>P>0.02 \\
\end{array}$ & $\begin{array}{c}+25 \\
13 \\
1.9(1) \\
0.4>P>0.3 \\
\end{array}$ & $\begin{array}{c}-2.5 \\
0.5 \\
4.7(3) \\
0.02>P>0.01 \\
\end{array}$ & $\begin{array}{c}-0.2 \\
0.1 \\
2.9(3) \\
0.1>P>0.05 \\
\end{array}$ & $\begin{array}{c}-0.6 \\
0.1 \\
11.4(1) \\
0.1>P>0.05 \\
\end{array}$ \\
\hline $\begin{array}{l}\text { Methyl prednisolone } \\
\text { Mean difference* } \\
\text { S.E. of difference } \\
\mathbf{t}(\mathrm{D} \text {. of } \mathrm{F} \text {.) } \\
\mathbf{P}\end{array}$ & $\begin{array}{c}+49 \\
9.2 \\
5.4(3) \\
0.02>P>0.01 \\
\end{array}$ & $\begin{array}{c}+22 \\
12.5 \\
1.7(3) \\
0.2>P>0.1 \\
\end{array}$ & $\begin{array}{c}+47 \\
20.1 \\
2 \cdot 3(3) \\
0 \cdot 2>P>0.1\end{array}$ & $\begin{array}{c}-3.6 \\
0.5 \\
7.5(3) \\
0.01>P>0.001\end{array}$ & $\begin{array}{c}-0.2 \\
0.001 \\
2.9(3) \\
0.1>P>0.05\end{array}$ & $\begin{array}{c}-0.5 \\
0.003 \\
16.4(3) \\
P<0.001\end{array}$ \\
\hline $\begin{array}{l}\text { Aldosterone } \\
\text { Mean difference* } \\
\text { S.E. of difference } \\
t \text { (D. of F.) } \\
\mathbf{P}\end{array}$ & $\begin{array}{c}+29 \\
7.5 \\
3.8(3) \\
0.05>P>0.02\end{array}$ & $\begin{array}{c}+39 \\
10.9 \\
3.6(3) \\
0.05>P>0.02\end{array}$ & $\begin{array}{c}+64 \\
24.1 \\
2 \cdot 7(2) \\
0 \cdot 2>P>0.1\end{array}$ & $\begin{array}{c}-2.9 \\
0.4 \\
6.4(3) \\
0.01>P>0.001\end{array}$ & $\begin{array}{c}-0.3 \\
0.004 \\
3.4(3) \\
0.05>P>0.02\end{array}$ & $\begin{array}{c}-0.6 \\
0.01 \\
69.2(2) \\
P<0.001\end{array}$ \\
\hline
\end{tabular}

*Test values minus control values. 
these received cortisone and three methyl prednisolone in the doses described above. The sections were examined histologically and differential cell counts were made with the help of an eyepiece micrometer. Twenty squares (each 0.01 sq. $\mathrm{mm}$. in area) were counted in each section, 10 at a standard distance $(0.03-0.04 \mathrm{~mm}$.) from the mucosal surface and 10 at a standard distance (0.02$0.03 \mathrm{~mm}$.) from the muscularis mucosae.

\section{RESULTS}

Volume.-The unstimulated basal juice was affected very little. Corticotrophin and aldosterone, however, caused a slight but consistent reduction. The response to histamine and to meat extract was increased consistently. In a subsidiary experiment, cortisone, in a dose of $50 \mathrm{mg}$. per day, caused a threefold increase in volume of the unstimulated juice in one of two dogs. Table I summarizes these results.

SeCretion of ACID.-The $p \mathrm{H}$ was reduced and the concentration of free acid was increased con- sistently by corticotrophin and all the steroids (Table II). The most striking effect was seen in the basal unstimulated juice which was usually neutral (mean $p \mathrm{H} \mathrm{5.8)}$ under control conditions and highly acid (mean $p \mathrm{H} 2.9$ ) during the administration of corticotrophin and all the steroids. The effects were not observed until these substances had been given for three to five days. In a subsidiary experiment this effect on basal juice was also produced by cortisone in a dose of $50 \mathrm{mg}$. per day; $25 \mathrm{mg}$. per day had a slight effect but $12 \cdot 5 \mathrm{mg}$. had none.

Maximal Secretory Response.-The maximal secretory response to histamine was tested in four dogs under control conditions and again when they were receiving cortisone. The pouches were usually secreting maximally between four and four and a half hours after the first injection of histamine. After this time the rate of secretion fell even with increasing doses. The results have been calculated in terms of

TABLE III

TOTAL VOLUME OF GASTRIC JUICE AND QUANTITY OF FREE HCI SECRETED IN RESPONSE TO INCREASING DOSES OF HISTAMINE

\begin{tabular}{|c|c|c|c|c|c|c|c|}
\hline Dog & $\begin{array}{l}\text { No. of } \\
\text { Tests }\end{array}$ & $\begin{array}{l}\text { Control } \\
\text { (mean) }\end{array}$ & $\begin{array}{l}\text { No. of } \\
\text { Tests }\end{array}$ & $\begin{array}{c}\text { Cortisone } \\
\text { (mean) }\end{array}$ & \multicolumn{3}{|c|}{ Difference } \\
\hline $\begin{array}{c}\text { Volume }(\mathrm{ml} .) \\
159 \\
196 \\
201 \\
202\end{array}$ & $\begin{array}{l}1 \\
1 \\
2 \\
2\end{array}$ & $\begin{array}{r}122.6 \\
126.2 \\
95.6 \\
121.3\end{array}$ & $\begin{array}{l}1 \\
1 \\
2 \\
3\end{array}$ & $\begin{array}{l}138 \cdot 3 \\
218 \cdot 3 \\
162 \cdot 3 \\
220 \cdot 4\end{array}$ & $\begin{array}{l}+15.7 \\
+92.1 \\
+66.7 \\
+99.1\end{array}$ & $\left.\begin{array}{l}+13 \% \\
+73 \% \\
+70 \% \\
+82 \%\end{array}\right\}$ & $\begin{array}{l}\text { Mean } \\
+59 \%\end{array}$ \\
\hline Statistical analysis: & $t=3.6$ & \multicolumn{6}{|c|}{ D.F. $=3 \quad 0.05>P>0.02$} \\
\hline Statistical analysis: & $t=4.74$ & \multicolumn{6}{|c|}{$0.02>P>0.01$} \\
\hline
\end{tabular}

TABLE IV

VOLUME OF GASTRIC JUICE, CONCENTRATION OF FREE HCl, AND QUUANTITY OF FREE HCl OBTAINED IN THE 15-MINUTE PERIOD OF MAXIMAL RESPONSE TO INCREASING DOSES OF HISTAMINE

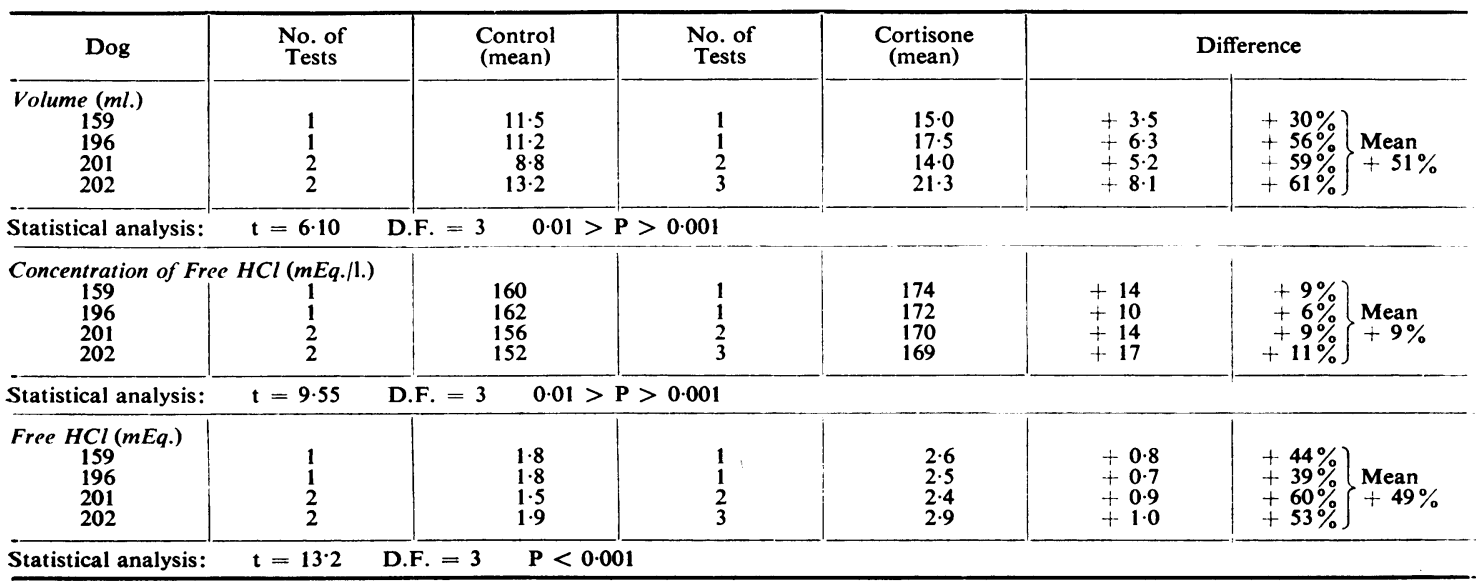


secretion during the four and a half-hour period (Table III). The total volume of juice secreted was increased greatly by cortisone in all the animals. The total amount of free $\mathrm{HCl}$ was about doubled in three of them and increased by one third in the fourth. The rate of secretion increased initially more rapidly when the dogs were receiving cortisone than it did during the control period. The maximum or "peak" rate was observed at about the same time in all the tests. The volume of juice, concentration of free $\mathrm{HCl}$, and quantity of free $\mathrm{HCl}$ secreted during the 15-minute period of maximal response were increased appreciably by cortisone (Table IV).

SeCretion of Pepsin.-The secretion of pepsin was not affected much (Table V). If anything its concentration in the juice was reduced by all the substances and in the case of the basal secretion of dogs receiving methyl prednisolone the reduction was substantial.

TABLE V

EFFECT OF CORTICOTROPHIN AND CORTICOIDS ON PEPSIN IN GASTRIC JUICE

\begin{tabular}{|c|c|c|c|}
\hline & \multicolumn{3}{|c|}{ Mean Pepsin Concentration (Mett units) } \\
\hline & \multirow{2}{*}{ Unstimulated } & \multicolumn{2}{|c|}{ Stimulated } \\
\hline & & Histamine & Meat Extract \\
\hline Control & 962 & 116 & $39 \cdot 0$ \\
\hline $\begin{array}{l}\text { Corticotrophin } \\
\text { Mean difference* } \\
\text { S.E. of difference } \\
\text { t (D. of F.) } \\
\text { P }\end{array}$ & $\begin{array}{c}-14 \\
108 \\
0.1(3) \\
P>0.9\end{array}$ & $\begin{array}{l}-22 \\
22 \\
0.02(3) \\
P>0.9\end{array}$ & $\begin{array}{c}+4.0 \\
8.1 \\
0.36(2) \\
0.8>P>0.7\end{array}$ \\
\hline $\begin{array}{l}\text { Cortisone } \\
\text { Mean difference* } \\
\text { S.E. of difference } \\
\text { t (D. of F.) } \\
\text { P }\end{array}$ & $\begin{array}{c}-379 \\
876 \\
0.4(3) \\
0.7>P>0.6\end{array}$ & $\begin{array}{c}-51 \\
25 \\
2.0(3) \\
0.2>\mathrm{P}>0.1\end{array}$ & $\begin{array}{c}+7.5 \\
6.5 \\
1.2(1) \\
0.5>\mathrm{P}>0.4\end{array}$ \\
\hline $\begin{array}{l}\text { Methyl prednisolone } \\
\text { Mean difference* } \\
\text { S.E. of difference } \\
\text { t (D. of F.) } \\
\text { P }\end{array}$ & 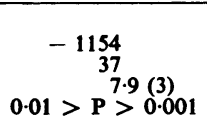 & $\begin{array}{c}-61 \\
34 \\
1.7(3) \\
0.2>P>0.1\end{array}$ & $\begin{array}{c}-2.8 \\
17.5 \\
0.2(3) \\
0.9>P>0.8\end{array}$ \\
\hline $\begin{array}{l}\text { Aldosterone } \\
\text { Mean difference* } \\
\text { S.E. of difference } \\
t \text { (D. of F.) } \\
\text { P }\end{array}$ & $\begin{array}{c}-128 \\
102 \\
1.3(3) \\
0.3>P \geqslant 0.2\end{array}$ & $\begin{array}{c}-22 \\
32 \\
0.7(3) \\
0.6>P>0.5\end{array}$ & $\begin{array}{c}-1.3 \\
8.3 \\
0.2(2) \\
0.9>P>0.8\end{array}$ \\
\hline
\end{tabular}

*Test values minus control values.

TABLE VI

EFFECT OF CORTICOTROPHIN AND CORTICOIDS ON VISCOSITY OF GASTRIC JUICE

\begin{tabular}{|c|c|c|c|}
\hline & \multicolumn{3}{|c|}{ Mean Viscosity (seconds) } \\
\hline & \multirow{2}{*}{ Unstimulated } & \multicolumn{2}{|c|}{ Stimulated } \\
\hline & & Histamine & Meat Extract \\
\hline Control & $19 \cdot 6$ & $8 \cdot 4$ & $8 \cdot 2$ \\
\hline $\begin{array}{l}\text { Corticotrophin } \\
\text { Mean difference* } \\
\text { S.E. of difference } \\
t \text { (D. of F.) } \\
\text { P }\end{array}$ & $\begin{array}{c}-7.5 \\
3.5 \\
2 \cdot 1(3) \\
0.2>P>0.1\end{array}$ & $\begin{array}{c}-0.2 \\
1.3 \\
0.5(3) \\
0.8>P>0.7\end{array}$ & $\begin{array}{l}\stackrel{0}{0 \cdot 1} \\
{ }^{0}(2) \\
P\end{array}$ \\
\hline $\begin{array}{l}\text { Cortisone } \\
\text { Mean difference* } \\
\text { S.E. of difference } \\
t(D \text {. of } F \text {.) } \\
\text { P }\end{array}$ & $\begin{array}{c}-6.0 \\
3.0 \\
2.0(3) \\
0.2>P>0.1\end{array}$ & $\begin{array}{l}\begin{array}{l}0 \\
1 \\
0\end{array}{ }^{>}(3) \\
\end{array}$ & $\begin{array}{l}{ }_{0}^{0.4} \\
0_{0}(1) \\
P\end{array}$ \\
\hline $\begin{array}{l}\text { Methyl prednisolone } \\
\text { Mean difference* } \\
\text { S.E. of difference } \\
t \text { (D. of F.) } \\
\text { P }\end{array}$ & $\begin{array}{c}-3.0 \\
4.2 \\
0.7(3) \\
0.6>P>0.5\end{array}$ & $\begin{array}{c}+1.7 \\
0.7 \\
2.4(3) \\
0.1>P>0.05\end{array}$ & $\begin{array}{c}+2.0 \\
0.6 \\
3.6(3) \\
0.05>P>0.02\end{array}$ \\
\hline $\begin{array}{l}\text { Aldosterone } \\
\text { Mean difference* } \\
\text { S.E. of difference } \\
\mathbf{t}(\mathrm{D} \text {. of } \mathrm{F} \text {.) } \\
\text { P }\end{array}$ & $\begin{array}{c}-7.1 \\
3.8 \\
1.9(3) \\
0.2>P>>0.1\end{array}$ & $\begin{array}{c}+0.3 \\
1.2 \\
0.5(3) \\
0.8>\mathrm{P}>0.7\end{array}$ & $\begin{array}{c}+0.5 \\
0.4 \\
0.4(2) \\
0.3>P>0.2\end{array}$ \\
\hline
\end{tabular}


SeCretion OF Mucus.-The viscosity of the resting juice tended to be lower in the test periods than in the control ones, but the differences were not significant (Table VI). The protein content of the juice secreted in response to maximal histamine stimulation was measured in two dogs (Table VII). Cortisone caused a reduction of $25 \%$.

TABLE VII

EFFECT OF CORTISONE ON PROTEIN CONTENT OF GASTRIC JUICE

\begin{tabular}{c|c|c}
\hline Dog & $\begin{array}{c}\text { Control } \\
\text { (mg./1.) }\end{array}$ & $\begin{array}{c}\text { Cortisone } \\
\text { (mg./1.) }\end{array}$ \\
\hline 201 & 150 & 182 \\
202 & 250 & $\begin{array}{c}111 \\
171 \\
136\end{array}$ \\
\hline Mean & 200 & 150 \\
\hline
\end{tabular}

SECRETION OF EleCtrolytes.-The concentration of sodium was reduced considerably and that of potassium (Table VIII) slightly by all the substances. The concentration of chloride was not affected.
Cellular Structure of Gastric Mucosa.-On naked-eye examination of the stomachs post mortem the mucosa of those dogs which had received corticoids appeared redder than those of the controls. Two of the dogs which had received cortisone had small petechial haemorrhages, but there was no obvious ulceration.

Microscopically no obvious lesions were present and the height of the mucosa and the number of mucosal folds were the same in the control as in the test groups.

The differential cell counts (Table IX) showed that the number of parietal cells was increased by about $50 \%$ and the number of peptic cells decreased by about $36 \%$ in the dogs which had received corticoids. In the control dogs there were more parietal cells than peptic cells in the superficial part of the mucosa (0.03-0.04 mm. from the surface) and more peptic than parietal cells in the deeper part. In the test dogs the parietal outnumbered the peptic cells in all parts of the mucosa.

TABLE VIII

EFFECT OF CORTICOTROPHIN AND CORTICOIDS ON CONCENTRATIONS OF SODIUM, POTASSIUM, AND CHLORIDE IN GASTRIC JUICE

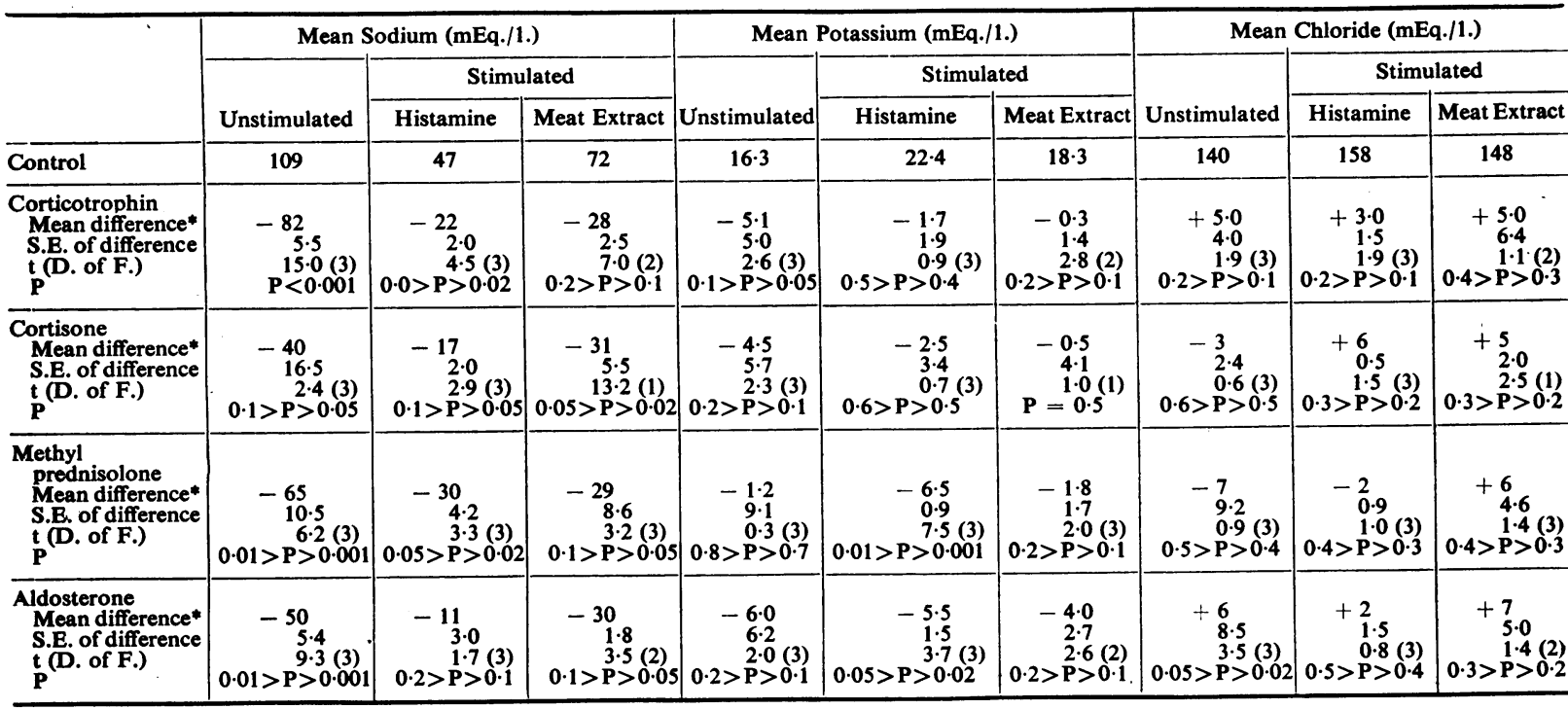

*Test values minus control values.

TABLE IX

EFFECTS OF CORTISONE AND OF METHYL PREDNISOLONE ON NUMBERS OF PARIETAL AND PEPTIC CELLS IN GASTRIC MUCOSA

\begin{tabular}{|c|c|c|}
\hline & Parietal Cells & Peptic Cells \\
\hline $\begin{array}{l}\text { Controls } \\
\text { Cortisone } \\
\text { Methyl prednisolone }\end{array}$ & $\left.\begin{array}{l}1,580 \\
1,570\end{array}\right\} \begin{array}{l}1,040 * \text { (S.D.126) } \ddagger \\
1,575 \text { (S.D.156) } \dagger\end{array}$ & 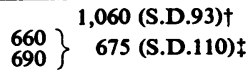 \\
\hline
\end{tabular}

*All figures are means and refer to cells per sq. mm. of field.

Comparison of the two means, $t=5.90$ D.F. $=9, P<0.001$.

+ Comparison of the two means, $t=6.42$ D.F. $=9, \mathrm{P}<0.001$. 


\section{Discussion}

These results confirm that the secretions of the adrenal cortex, in pharmacological doses, exert an influence on gastric secretion.

Corticotrophin and cortisone stimulate the secretion of acid in the basal juice and augment its secretion in response to histamine and antral stimulation. Moreover, cortisone increases the maximal secretory response to histamine. All but one of these observations (the effect on the basal juice) can be explained by the increase in number of the parietal cells in the gastric mucosa which our preliminary studies have shown. Moreover, the delay of three to four days before any effect is observed may well reflect the time required for the cells to multiply. A simple increase in the number of acid-secreting cells, however, does not explain the observation that the basal juice regularly contains free acid under the influence of corticotrophin and cortisone while it rarely does so under control conditions. It must be concluded that these substances stimulate the parietal cells to secrete as well as to divide.

Two sets of observations indicate that hydrogen ion secretion is stimulated directly and that the effect is not dependent on the behaviour of other electrolyte ions. The first is the finding that the concentrations of sodium and potassium are reduced and that that of chloride is unchanged. If these ions were affected primarily, as they are in the kidney and in the sweat glands, the sodium and chloride would be reduced and the potassium increased. The second is the finding that methyl prednisolone (a relatively pure glucocorticoid) influences the secretion of acid and of electrolytes in the same way as cortisone does. If the primary action were on the metallic ions, methyl prednisolone would be expected to have a lesser effect on them. It is likely that the reduction in sodium and potassium ions is related to the increase in hydrogen ions in the gastric juice.

The stimulatory effect is still unexplained. The fact that aldosterone (of which the glucocorticoid action is minimal) and methyl prednisolone (of which the mineralocorticoid action is minimal) have the same influence on gastric secretion as cortisone does indicates that the effect is not dependent on their main metabolic properties.

The method which was used for the estimation of pepsin is not a very accurate one and little weight can be attached to the results. However, the tendency for its concentration to be reduced is consistent with the apparent reduction in the number of peptic cells observed histologically.
The effects of corticoids on the secretion of mucus still await full investigation. Our limited results suggest that the secretion is reduced. It may be, as has been suggested (Hirschowitz et al., 1955), that the lowering of the defensive mucous barrier is one factor in the pathogenesis of steroid ulceration. Another, clearly, is the increase of acid secretion, particularly in the empty stomach.

We wish to thank the following for their help: Mr. H. O. Nevin, Mr. J. Tansey, Mr. F. Mullan, Miss M. A. Pountain, and Mr. J. Mullan for technical assistance; the technical staff of the biochemical laboratories, Royal Victoria Hospital, Belfast; Dr. J. B. Gibson for his help with the histology; Miss B. H. S. Foster and Miss H. N. Pountain for the secretarial work; Roussel Ltd. and Dr. E. W. Tapley for the gift of a $p \mathrm{H}$ meter and for supplies of cortisone; Upjohn Ltd. and Dr. A. R. H. Hicks for supplies of methyl prednisolone ("medrone"); Ciba Laboratories Ltd. and Dr. C. D. Falconer for supplies of aldosterone.

\section{REFERENCES}

Carbone, J. V., and Liebowitz, D. (1958). Metabolism, 7, 70

Code, C. F., Blackburn, C. M., Livermore, G. R., and Ratke, H. V. (1949). Gastroenterology, 13, 573.

and Mitchell, R. G. (1953). Abstracts of Communications 19th International Physiological Congress, Montreal, p. 274.

Dreiling, D. A., Janowitz, H. D., and Rolbin, H. L. (1958). Amer. J. Gastroent., 30, 269.

Escamilla, R. F., and Lisser, H. (1942). J. clin. Endocr., 2, 65.

French, J. D., Longmire, R. L., Porter, R. W., and Movius, H. J. (1953). Surgery, 34, 621.

Gray, S. J., Benson, J. A., Reifenstein, R. W., and Spiro, H. M. (195ia). J. Amer. med. Ass., 147, 1529.

, Spiro, H. M., and Reifenstein, R. W. (1951b). Gastroenterology, 19, 658.

Hawk, P. B., Oser, B. L., and Summerson, W. H. (1952). Practical Physiological Chemistry, Churchill, London.

Hirschowitz, B. I., London, J. L., and Pollard, H. M. (1957). Gastroenterology, 32, 85 .

- Streeten, D. H. P., Pollard, H. M., and Boldt, H. A. (1955). J. Amer. med. Ass., 158, 27.

Kelemen, E., and Bikich, G. (1956). Acta haemat. (Basel), 15, 202. Kyle, J. (1955). Lancet, $2,724$.

, Logan, J. S., Neill, D. W., and Welbourn, R. B. (1956). Ibid., $1,664$.

McGee, L. S., Blackburn, J., Lance, E. M., and Scott, H. W. (1959). Surg. Forum 1958, 9, 440.

Mitchell, R. G., and Code, C. F. (1954). J. clin Endocr., 14, 707.

Oka, M., and Aho, J. (1957). Acta rheum. scand., 3, 68.

Plainos, T. C., and Phillippu, A. J. (1958.) Gastroenterology, 35, 183.

Ragins, H., Dragstedt, L. R., Landor, J. H., Lyon, E. S., and Dragstedt, L. R.' (1956).' Surgery, 40, 886.

Rowntree, L. G., and Snell, A. M. (1931), A Clinical Study of Addison's Disease, W. B. Saunders, Philadelphia and London.

Schales, O., and Schales, S. S. (1941). J. biol. Chem., 140, 879.

Sigel, B., Bassett, J. G., and Cooper, D. R. (1957). Surg. Forum 1956, 7, 362 .

Stempien, S. J., and Dagradi, A. (1954). Gastroenterology, $27,358$.

Villareal, R., Ganong, W. F., and Gray, S. J. (1955). Amer.J. Physiol., 183,485 .

Welbourn, R. B., and Code, C. F. (1953). Gastroenterology, 23, 356. Wiederanders, R. E., Classen, K. L., and Gobbel, W. G. (1959). Surg. Forum, 1958, 9, 434 .

Winkelstein. A (1957). Amer. J. Gastroent, 27, 584.

Zubiran, J. M., Kark, A. E., and Dragstedt, L. R. (1952a). Gastro-

enterology, 21, 276. .
Kark, A. E., Montalbetti, A. J., Morel, C. J. L., and Dragstedt L. R. (1952b). A.M.A. Arch. Surg., 65, 809. 